\title{
The sintering characteristics of fly ash-clay system with mine tailing
}

\author{
Kyung Nam Kim, Dong Myung Woo and Hyun Park ${ }^{\dagger}$ \\ Department of Advanced Materials Engineering, Kangwon National University, Samcheok 245-711, Korea \\ (Received September 8, 2011) \\ (Revised October 24, 2011) \\ (Accepted November 4, 2011)
}

\begin{abstract}
This research was performed to stabilize heavy metals in mine tailing using fly ash and clay. Fly ash-clay-mine tailing system were investigated using XRD (X-ray diffractometer), XRF (X-ray fluorescence spectrometer), TG-DTA, SEM (Scanning Electron Microscope), Dilatometer and UTM with various mine tailing contents $(\sim 15 \mathrm{wt} \%)$. The fly ash used in this research was mainly composed of $\mathrm{SiO}_{2}$ (33.01 wt \%), $\mathrm{Al}_{2} \mathrm{O}_{3}(28.54 \mathrm{wt} \%), \mathrm{K}_{2} \mathrm{O}$ (3.32 wt $\%$ ), $\mathrm{Fe}_{2} \mathrm{O}_{3}(1.47 \mathrm{wt} \%), \mathrm{CaO}$ ( $9.97 \mathrm{wt} \%) . \mathrm{SiO}_{2}$ and $\mathrm{Al}_{2} \mathrm{O}_{3}$ composition of the clay was over $61 \mathrm{wt} \%$. And the mine tailing have high composition of $\mathrm{SiO}_{2}$ (26.91 wt \%), $\mathrm{CaO}(24.25 \mathrm{wt} \%), \mathrm{Fe}_{2} \mathrm{O}_{3}(22.97 \mathrm{wt} \%)$. Therefore, it was estimated that fly ash-clay-mine tailing have enough sintering characteristics. The shrinkage of specimens started at around $850^{\circ} \mathrm{C}$ and changed little up to $1100^{\circ} \mathrm{C}$, but increased markedly at above $1100^{\circ} \mathrm{C}$. The shrinkage rate is strongly related to the decarbonization amount of coal fly ash. As the result of SEM, structure of the specimens with mine tailing addition showed more close than the one without mine tailing. Compressive strength of the specimens with mine tailing was highly increased to approximately $200 \sim 420 \mathrm{kgf} / \mathrm{cm}^{2}$, it satisfied the first grade criterion for clay brick by KS L 4201. The specification of leaching characteristics of the sintered specimens were within the Korean regulation standard.
\end{abstract}

Key words Fly ash, Clay, Mine tailing

\section{플라이애쉬-점토-광미계의 소결특성}

\author{
김경남, 우동명, 박현 \\ 강원대학교(삼척) 신소재공학과, 삼척, 245-711 \\ (2011년 9월 8일 접수) \\ (2011년 10월 24일 심사완료) \\ (2011년 11월 4일 게재확정)
}

요 약 본 연구는 석탄회(Fly Ash)와 점토를 이용하여 광미(tailing)의 중금속 안정화를 연구하였다. 플라이애쉬-점토-광 미계의 특성은 여러 분석기기(SEM, XRD, XRF, TG-DTA, Dilatometer, UTM)를 이용하여 광미의 첨가량에 따른 물리·화학 적 특성을 조사하였다. 플라이애쉬의 화학조성은 $\mathrm{SiO}_{2}$ 가 $33.01 \mathrm{wt} \%, \mathrm{Al}_{2} \mathrm{O}_{3}$ 는 $28.54 \mathrm{wt} \%, \mathrm{CaO}$ 가 $9.97 \mathrm{wt} \%$ 이고 이외에 $\mathrm{Fe}_{2} \mathrm{O}_{3}$ 와 알카리 성분 등을 함유하고 있으며, 강열감량은 플라이애쉬가 $20.26 \mathrm{wt} \%$ 로 나타났다. 플라이애쉬의 $\mathrm{SiO}_{2}$ 와 $\mathrm{Al}_{2} \mathrm{O}_{3}$ 조성 양은 점토성분이 $61 \mathrm{wt} \%$ 이상이다. 그리고 광미의 화학조성은 $\mathrm{SiO}_{2}$ 가 $26.91 \mathrm{wt} \%, \mathrm{CaO}$ 가 $24.25 \mathrm{wt} \%, \mathrm{Fe}_{2} \mathrm{O}_{3}$ 는 $22.97 \mathrm{wt} \%$ 이다. 그러므로 플라이애쉬-점토-광미계에서 플라이애쉬가 점토의 원료로 대체가 가능하다. 시편의 수축은 $850^{\circ} \mathrm{C}$ 부근에서 서서 히 수축이 시작되어 $1100^{\circ} \mathrm{C}$ 부근에서 급격하게 수축하는 것을 볼 수 있었으며 플라이애쉬의 탄화 분해 과정에 의해 영향 을 받는다. 시편의 미세구조는 광미를 첨가한 시편이 치밀하였다. 열처리 온도에 따른 물리적 특성 조사를 위하여 흡수율 과 압축강도를 측정하였으며 광미를 첨가한 시편의 압축강도가 높으며 약 $200 ~ 420 \mathrm{kgf} / \mathrm{cm}^{2}$ 로 KS L 4201의 점토 블록 기준 내에 있다. 그리고 광미의 중금속의 안정화는 소결한 후에 한국폐기물 규격내에서 안정화한 것을 알 수 있다.

\section{1. 서 론}

최근 에너지 수요가 급증함에 따라 세계적으로 매장량 이 풍부하고, 가격이 저렴하며 공급원이 안정된 석탄의

\footnotetext{
Corresponding author

Tel: $+82-33-570-6564$

Fax: +82-33-570-6557

E-mail: hipark@kangwon.ac.kr
}

수요는 꾸준히 증가하고 있다. 그러나 화력발전소에 사 용된 석탄은 부산물로 석탄회(coal ash)를 발생 시키는 데, 2010년에는 약 600만톤 까지 증가할 것으로 예상된 다[1,2]. 화력발전소에서 생성되는 석탄회는 보통 비산 재인 fly ash(비회)와 바닥재인 bottom ash(저회)로 구분 되어진다. Fly ash는 보일러 로 내에서 미연탄소 연소시 $\mathrm{ash}$ 성분 입자가 연소가스와 흐르면서 절탄기, 공기예열 기 및 전기집진기에서 포집되는 ash를 지칭한다. Bottom 
$\mathrm{ash}$ 는 전체 ash 발생량의 약 $1040 \%$ 정도이며 fly ash 는 전체량의 약 $6080 \%$ 에 이르고 있다[3]. 석탄회의 재 활용을 위한 연구는 부족한 자원의 확보 차원과 최근 환 경보존 문제 및 경제적 측면에서 매우 중요시 되고 있어 석탄회가 선진국에서는 '제 3 의 자원'으로 고려되어지고 있다. 선진국에서는 석탄회의 재활용률이 $60 \%$ 로서 시 멘트분야, 골재, 토목, 건축자재 등에 광범위하게 재활용 되고 있다 $[2,4]$.

그리고 광미(tailing)는 광산 폐기물로 광석채굴시 발생 하는 폐석(waste rock)과 광석광물(ore mineral)을 회수 하기 위한 선광공정에서 발생하는 것이다. 휴-폐광 이후 광산폐기물에 대한 적절한 환경복원시설을 설치하지 않 아 광산주변에 그대로 방치되거나 광산 및 주변지역에 매립되어 있어 집중강우 혹은 붕괴로 인해 유실, 강풍에 의해 주변지역으로 이동 분산, 중금속 용출 등으로 주변 의 토양, 농경지, 지하수, 주변 수계를 오염시키고 있다 [5].

광산 폐기물의 재활용으로 물질회수(materials recovery) 법과 물질전환(materials conversion)법으로 분류하고 있 으나 물질회수법은 유가물질 회수 차원에서는 경제적으 로 유리하나 폐기물 전량을 재활용할 수 없을 뿐만 아니 라 유가물질 회수공정에서 2 차 오염을 발생시킬 수 있 다. 따라서 광미 자체를 순환자원화하는 방안으로 고형 화 - 안정화시켜 주변 환경영향을 최소화하기 위한 물질 전환법에 대한 연구가 활발히 진행되고 있다[6-8].

따라서, 이전 연구에서[9] 석탄 바닥재를 이용한 연구 를 하였으며, 본 연구에서는 광미내 중금속 고정화 방안 으로 플라이애쉬-광미-점토계를 이용하여 광미 첨가량에 따른 물리·화학적 특성과 중금속을 다량 함유한 광미의 용출특성 평가를 하여 환경안정성에 대하여 연구 하였다.

\section{2. 실험방법}

\section{1. 시편제조}

본 실험의 출발 원료는 강원 가곡연화 광미사와 $\mathrm{D}$ 화 력발전소의 플라이 애쉬를 사용하였으며 또한 $\mathrm{S}$ 사의 저

Table 1

Mixing ratio and sintering condition of raw materials (unit: wt\%)

\begin{tabular}{lllll}
\hline Sample & Fly ash & Clay & Tailing $(\%)$ & Sintering temp. $\left({ }^{\circ} \mathrm{C}\right)$ \\
\hline FCT0 & 20 & 80 & 0 & \\
FCT5 & 20 & 80 & 5 & $1000,1100,1150$ \\
FCT10 & 20 & 80 & 10 & \\
FCT15 & 20 & 80 & 15 & \\
\hline
\end{tabular}

F: Fly Ash, C: Clay(Sericite), T: Tailing
급 Sericite를 사용하였다. 시편의 조성은 석탄회와 점토 를 $20: 80 \mathrm{wt} \%$ 로 고정하고 광미의 첨가량을 $0,5,10$, $15 \mathrm{wt} \%$ 로 변화시켜 각각 제조하였으며 Table 1에 나타 내었다. 물리적 특성의 측정을 위해 각 시편을 $1,000 \mathrm{psi}$ 의 압력으로 일축 가압하여 직경 $10 \mathrm{~mm}$, 두께 $12 \mathrm{~mm}$ 의 디스크 형태로 공시체를 제조한 후 로에서 승온속도 를 분당 $5^{\circ} \mathrm{C}$ 로 $1150^{\circ} \mathrm{C}$ 까지 한 후 30 분간 유지하여 로 냉 하였다.

\section{2. 특성분석}

광미의 유해중금속(harmful heavy metal)의 함량을 안정화 처리 후 용출 농도를 확인하고자 Microwave digestion system으로 전처리 후 유도결합플라즈마 원자 방출분광기(ICP-AES; Vista-PRO, Varian, Australia)를 이용하여, $\mathrm{Pb}, \mathrm{As}, \mathrm{Cr}$ 을 대상으로 분석하였다.

원료의 화학성분을 조사하기 위하여 $\mathrm{X}$-선 형광분석기 (XRF; ZSX100e, Rigaku, Japan)를 이용하여 분석하였 으며 target은 $\mathrm{Rh}$ 을 사용하였다. 원료와 열처리 온도에 따른 결정상을 조사하기 위하여 $\mathrm{X}$-선 회절분석기(XRD: D/Max-2200, Rigaku, Japan)를 이용하였다. 열처리 온 도에 따른 열적특성을 조사하기 위하여 시차열분석기 (TG-DTA, STA409PC, Luxx, NETSCH, Germany)를 이용하여 $10^{\circ} \mathrm{C} / \mathrm{min}$ 의 승온속도로 $1250^{\circ} \mathrm{C}$ 까지 $\mathrm{Air}$ 분위 기에서 분석하였다.

시편의 치밀화 과정을 조사하기 위하여 열팽창계수 측 정기(Dilatometer, Unitherm model-1161, Anter Co., $\mathrm{USA}$ )를 이용하여 $10^{\circ} \mathrm{C} / \mathrm{min}$ 의 승온속도로 $1150^{\circ} \mathrm{C}$ 까지 측정하였다. 시편의 미세구조는 주사전자현미경 (SEM, JSM-5410, JEOL, Japan)을 이용하여 관찰하였다. 열처 리 온도와 조성에 따른 시편의 물리적 특성을 조사하기 위하여 흡수율, 진밀도 및 압축강도를 측정하였다. 흡수 율과 진밀도는 KS F 2503에 따라 측정하였으며, 압축 강도는 KS L 3305에 따라 만능시험기(UTM, 8801, INSTRON, USA)를 이용 하였으며 압축강도에서 측정 된 결과는 시편 5 개의 평균값으로 나타내었다.

광미 및 소성 후 시편의 중금속 용출특성은 폐기물공 정시험법(KSLT, Korean Standard Leaching Test)에 따라 전처리하고 유도결합플라즈마 원자방출분광기(ICP-AES; Vista-PRO, Varian, Australia)를 이용하여 분석하였다.

\section{3. 결과 및 고찰}

\section{1. 원료의 화학적 특성}

석탄회, 점토 와 광미에 대한 화학조성을 Table 2에 
Table 2

Chemical composition of raw materials

\begin{tabular}{|c|c|c|c|c|c|c|c|c|c|}
\hline \multirow{2}{*}{$\begin{array}{l}\text { Raw } \\
\text { materials }\end{array}$} & \multicolumn{9}{|c|}{ Chemical components (wt\%) } \\
\hline & $\mathrm{SiO}_{2}$ & $\mathrm{Al}_{2} \mathrm{O}_{3}$ & $\mathrm{CaO}$ & $\mathrm{MgO}$ & $\mathrm{SO}_{3}$ & $\mathrm{~K}_{2} \mathrm{O}$ & $\mathrm{Fe}_{2} \mathrm{O}_{3}$ & $\mathrm{Na}_{2} \mathrm{O}$ & Ig. loss \\
\hline Fly ash & 33.01 & 28.54 & 9.97 & 0.77 & 2.43 & 3.32 & 1.47 & 0.23 & 20.26 \\
\hline Clay & 68.54 & 17.18 & 2.02 & 1.01 & 0.03 & 6.71 & 0.92 & 0.14 & 3.45 \\
\hline Tailing & 26.91 & 3.42 & 24.25 & 0.86 & 14.39 & 0.59 & 22.97 & 0.06 & 6.55 \\
\hline
\end{tabular}

나타내었다. 플라이애쉬 화학조성이 $\mathrm{SiO}_{2}$ 가 $33.01 \mathrm{wt} \%$, $\mathrm{Al}_{2} \mathrm{O}_{3}$ 가 $28.54 \mathrm{wt} \%, \mathrm{CaO}$ 가 $9.97 \mathrm{wt} \%$ 이며 이외에 $\mathrm{K}_{2} \mathrm{O}$ 와 알칼리성분 등이 함유되어 있으며 강열감량이 $20.26 \mathrm{wt} \%$ 이다. 일반적으로 석탄회는 $\mathrm{Si}$ 와 $\mathrm{Al}$ 성분을 $80 \%$ 이상 함유하여 규산염광물(Aluminosilicate Minerals)과 유사 한 특성을 나타내며 $\mathrm{Ca}, \mathrm{Mg}, \mathrm{K}, \mathrm{Na}, \mathrm{Fe}$ 및 $\mathrm{S}$ 등의 원 소를 함유하고 있으므로, 점토의 대체 원료로서 석탄회 의 사용이 가능함을 알 수 있다.

ASTM 규정에서는 산화물의 주요 성분인 $\mathrm{SiO}_{2}, \mathrm{Al}_{2} \mathrm{O}_{3}$ 및 $\mathrm{Fe}_{2} \mathrm{O}_{3}$ 함유량으로 석탄회를 분류하는데, 3 종류의 산 화물이 차지하는 비율이 $70 \mathrm{wt} \%$ 이상인 경우에는 $\mathrm{F}$ 급 으로 분류하며, 3종류의 산화물이 차지하는 비율이 50 $70 \mathrm{wt} \%$ 이며 $\mathrm{CaO}$ 함유량이 $10 \mathrm{wt} \%$ 이상인 경우에는 C 급으로 분류한다[9]. 일반적으로 $\mathrm{C}$ 급 석탄회는 $\mathrm{F}$ 급에 비 하여 $\mathrm{CaO}, \mathrm{MgO}, \mathrm{SO}_{3}$ 의 함유량이 높고 $\mathrm{SiO}_{2}$ 와 $\mathrm{Al}_{2} \mathrm{O}_{3}$ 의 함유량이 낮다. 본 실험에서 사용하는 $\mathrm{D}$ 사의 Fly Ash는 $\mathrm{SiO}_{2}, \mathrm{Al}_{2} \mathrm{O}_{3}$ 및 $\mathrm{Fe}_{2} \mathrm{O}_{3}$ 함유량이 $70 \mathrm{wt} \%$ 이하이고 $9.97 \mathrm{wt} \%$ 의 $\mathrm{CaO}$ 를 함유하고 있어 $\mathrm{ASTM}$ 규정에 의해 $\mathrm{C}$ 급으로 분류할 수 있다. $\mathrm{Na}_{2} \mathrm{O}$ 와 $\mathrm{MgO}$ 와 같은 알칼리 성분이 미량 첨가되어 있어 $\mathrm{F}$ 급 석탄회는 반응성이 낮은 실리 케이트 결정을 형성하는데 반해 $\mathrm{CaO}$ 의 함유량이 많은 $\mathrm{C}$ 급 석탄회는 칼슘-알루미노실리케이트 결정체를 형성한 다 [10, 11].

광미의 화학적 조성은 $\mathrm{SiO}_{2} 26.91 \mathrm{wt} \%, \mathrm{Fe}_{2} \mathrm{O}_{3} 22.97$ $\mathrm{wt} \%, \mathrm{Al}_{2} \mathrm{O}_{3} 3.42 \mathrm{wt} \% \mathrm{CaO} 24.25 \mathrm{wt} \%, \mathrm{SO}_{3} 14.39 \mathrm{wt} \%$ 이고 강열감량은 $6.55 \mathrm{wt} \%$ 로 나타났다. 광미의 유해 중 금속 함량은 우리의 이전 연구결과에 광미의 유해중금속 함량은 As $191.3 \mathrm{mg} / \mathrm{l}, \mathrm{Pb} 425.6 \mathrm{mg} / \mathrm{l}, \mathrm{Cr}^{6+} 29.2 \mathrm{mg} / /$ 로 나타났다[9]. 일반 토양에 비하여 $\mathrm{Pb}$ 약 12 배 $\mathrm{As}$ 약 32 배, $\mathrm{Cr}$ 약 27배가 높게 나타났다. 이것은 광미내 중금속 의 오염이 심각한 것으로 판단되며 우수 및 바람 등에 의한 중금속 용출 및 비산으로 인한 주변 환경의 오염을 유발 할 가능성이 클 것으로 생각된다.

\section{2. 원료의 결정상}

석탄회와 점토 및 광미의의 $\mathrm{X}$-선 회절 분석 결과를 Fig. 1에 나타내었다. 원료물질인 플라이애쉬는 quartz, illite, moscovite, calcite가 관찰되고 있으며 이는 화학성

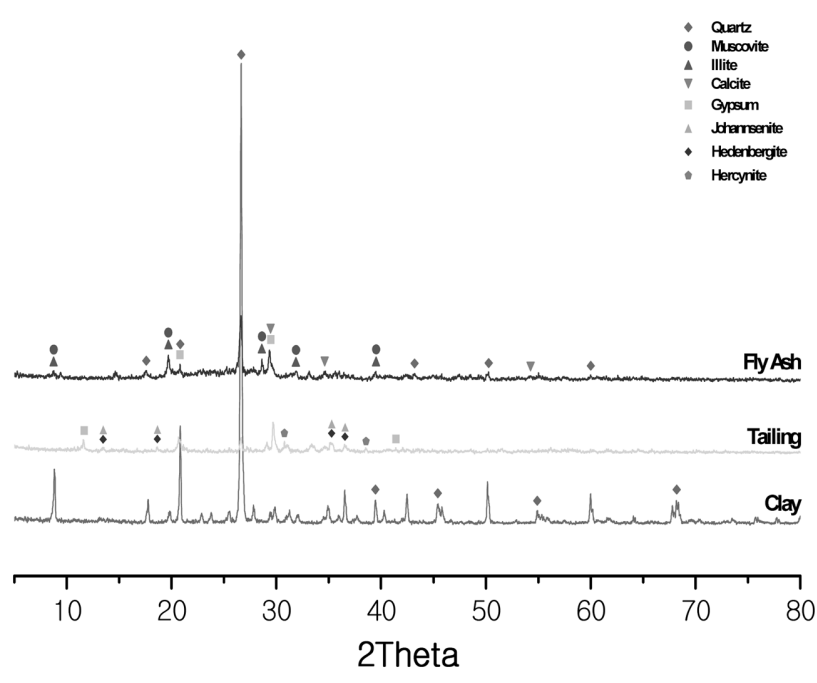

Fig. 1. XRD patterns of the raw materials.

분에서 $\mathrm{CaO}$ 성분이 높은 것과 일치하고 있다. Clay는 주 결정상이 quartz상이고 일부 알칼리 광물상이 나타나며, 광미는 gypsum, johannsenite, gypsum, hercynite가 관 찰되었다.

강원 가곡의 아연광석은 단독 광물로 산출되는 예는 거의 없고, 동, 연 등의 황화광을 수반한다. 채광된 조광 은 부유선광에 의해 아연 정광으로 만들어 제련한다. 산 화광물은 수용액 중에서나 대기 중에서 비교적 안정성을 보여주나 황화광물은 준안정(meta stable)한 상태이다. 즉, 대기 중이나 상온상압하의 수용액 중에서 대부분의 황화광물은 산화광이 되고 황 성분은 주위환경에 따라 그에 해당하는 황화물이나 $\mathrm{S}^{-2}$ 또는 유리황 등으로 존재 한다 $[12,13]$. 따라서 광미에 gypsum이 존재하며, Table 2의 화학성분에서 $\mathrm{Fe}_{2} \mathrm{O}_{3}$ 와 $\mathrm{SO}_{3}$ 가 다량 존재하는 것과도 잘 일치하고 있음을 알 수 있다.

\section{3. 원료의 열적특성}

석탄회와 점토의 열처리 온도에 따른 열적특성을 조사 하기 위하여 열분석(TG-DTA)을 행한 결과를 Fig. 2와 Fig. 3 에 각각 나타내었다. 석탄회는 $80 \sim 200^{\circ} \mathrm{C}$ 에서 흡열 피크를 동반한 중량감소와 $500 ~ 800^{\circ} \mathrm{C}$ 에서 발열피크를 동반한 중량감소가 관찰되었으며 전체 무게감량은 $22 \mathrm{wt} \%$ 


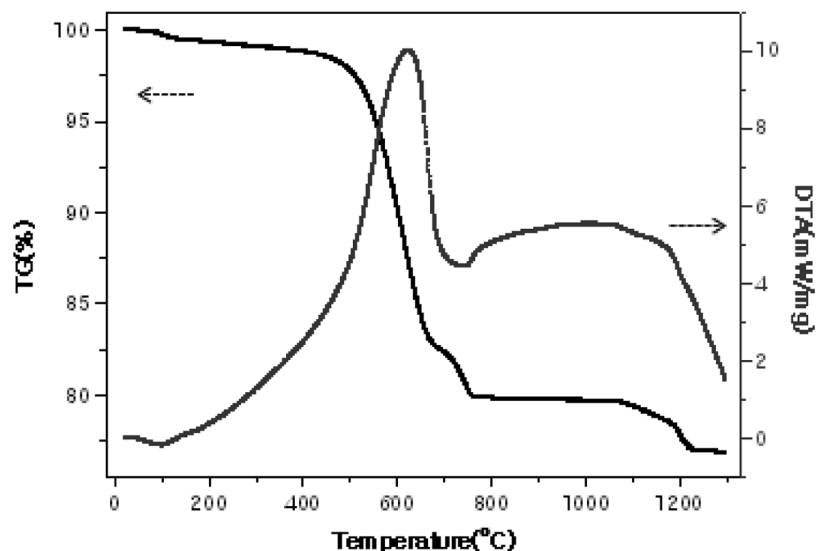

Fig. 2. TG-DTA analysis of fly ash [14].

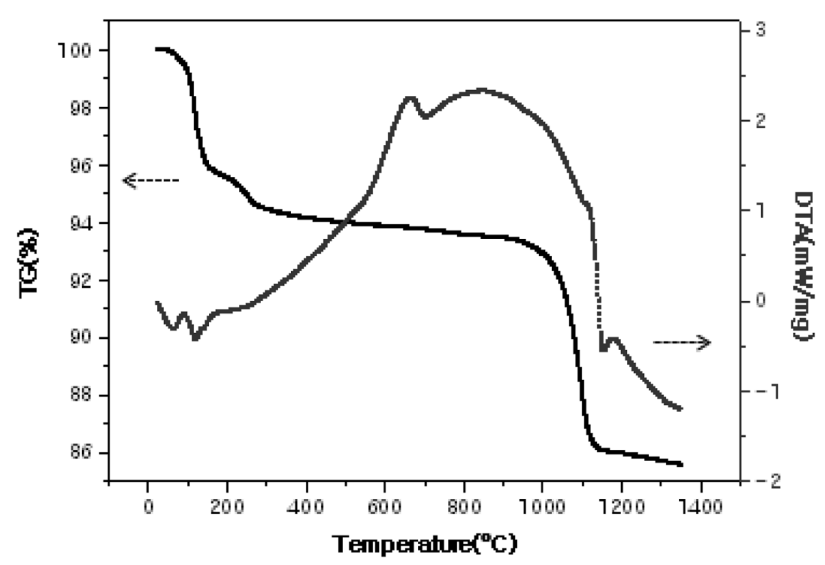

Fig. 3. TG-DTA analysis of tailing [9].

정도이다. 전자의 흡열피크를 동반한 중량감소는 석탄회 에 흡착되어 있는 흡착수의 이탈에 의한 것이며, 후자의 발열피크와 중량감소는 석탄회에 잔존한 미연탄소의 열 분해에 의한 것이다[14]. 광미는 $200^{\circ} \mathrm{C}$ 흡열피크를 동반 한 중량감소와 $1000^{\circ} \mathrm{C}$ 에서의 중량감소가 관찰되었다. 전자의 흡열피크를 동반한 중량감소는 광미시표의 표면 수와 흡착수가 탈수 된 것이며, $600^{\circ} \mathrm{C}$ 의 발열피크는 $\mathrm{CaSO}_{4} \rightarrow \mathrm{CaO}+\mathrm{SO}_{2}+1 / 2 \mathrm{O}_{2}$ 에 의한 것으로 생각된다[9].

\section{4. 시편의 수축률과 결정상}

석탄회-점토계에서 광미의 첨가량에 따른 시편의 수축 결과는 일정한 승온속도 하에서 연속적인 치밀화 과정을 조사하여 각각 Fig. 4에 나타내었다. 시편은 $900^{\circ} \mathrm{C}$ 부근 에서 시작되고 있으며, $1000^{\circ} \mathrm{C}$ 부근에서 서서히 수축이 되어 $1120^{\circ} \mathrm{C}$ 부근에서는 급격히 수축하는 것을 볼 수 있다. 전자의 수축은 광미내의 탄산칼슘의 분해반응에 의한 것으로 생각되며, 후자의 수축은 원료내의 알칼리 성분이 액상으로 되면서 치밀화가 급격하게 진행하는 것 으로 생각된다.

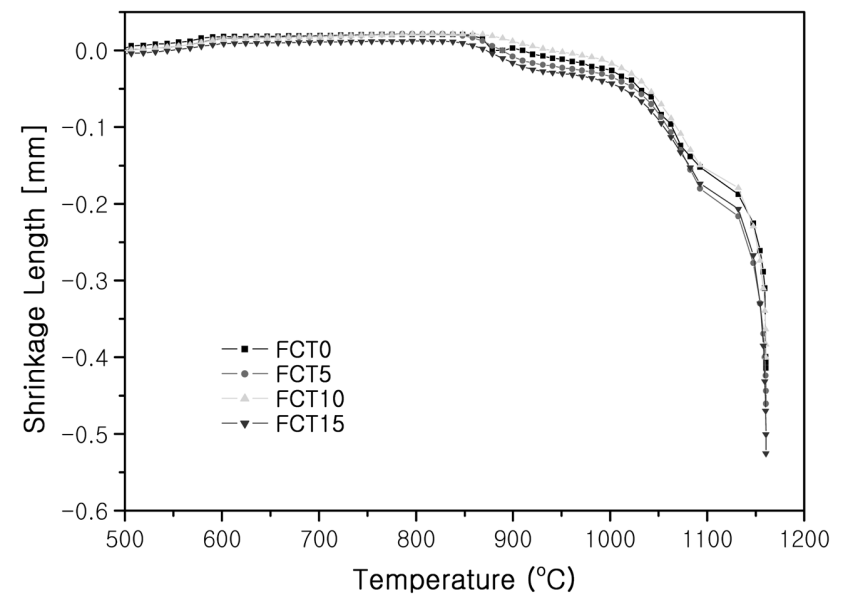

Fig. 4. Linear shrinkage as a function of temperature for the fly ash-clay-tailing systems (heating rate, $10^{\circ} \mathrm{C} / \mathrm{min}$ ).

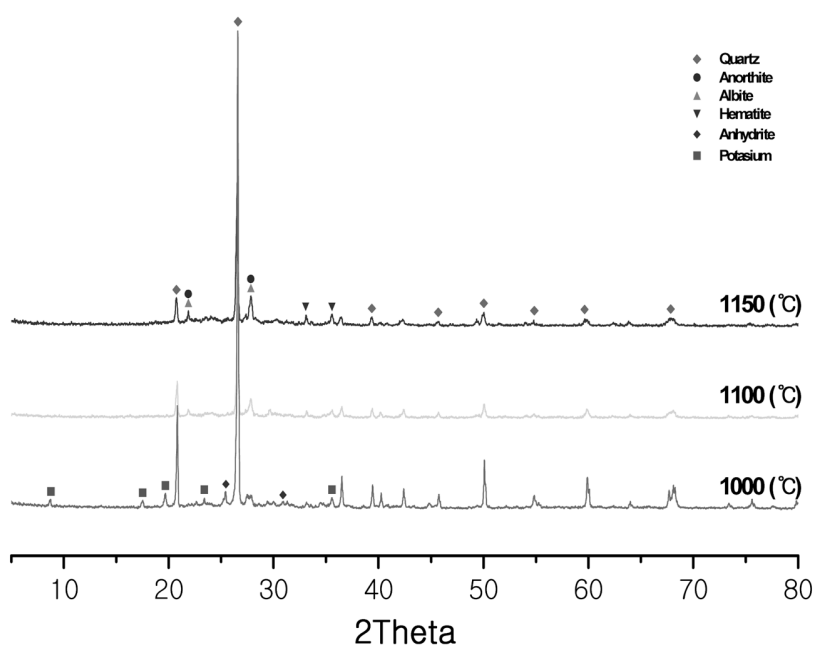

Fig. 5. XRD patterns of fly ash-clay-tailing systems heated at various temperatures.

소성 온도에 따른 시편의 결정상의 변화를 조사하고자 $1000,1100,1150^{\circ} \mathrm{C}$ 에서 30 분간 열처리한 석탄회-광미점토계(FCT15) 시료의 X-선 회절 분석 결과를 Fig. 5에 나타내었다. 주결정상은 quartz, anorthite, albite, hematite, anhydrite, potasium상이 관찰되었다. 소성온도가 증가함 에 따라 quartz상의 피크 intensity가 감소하였으며, anorthite의 피크는 증가하는 것을 볼 수 있다. 이는 광 미내의 $\mathrm{CaO}$ 성분이 $\mathrm{SiO}_{2}$ 와 $\mathrm{Al}_{2} \mathrm{O}_{3}$ 성분과 반응하여 anorthite상이 생성되었기 때문이다[15].

\section{5. 시편의 미세구조}

$1100^{\circ} \mathrm{C}$ 에서 소성된 시편의 미세구조를 Fig. 6에 나타 내었다. 모든 시료에서 크고 작은 기공들이 관찰되는데 이것은 원료물질인 석탄회의 미연탄소분의 열분해에 의 해 발생된 gas 팽창에 의한 것으로 생각된다. 그리고 광 

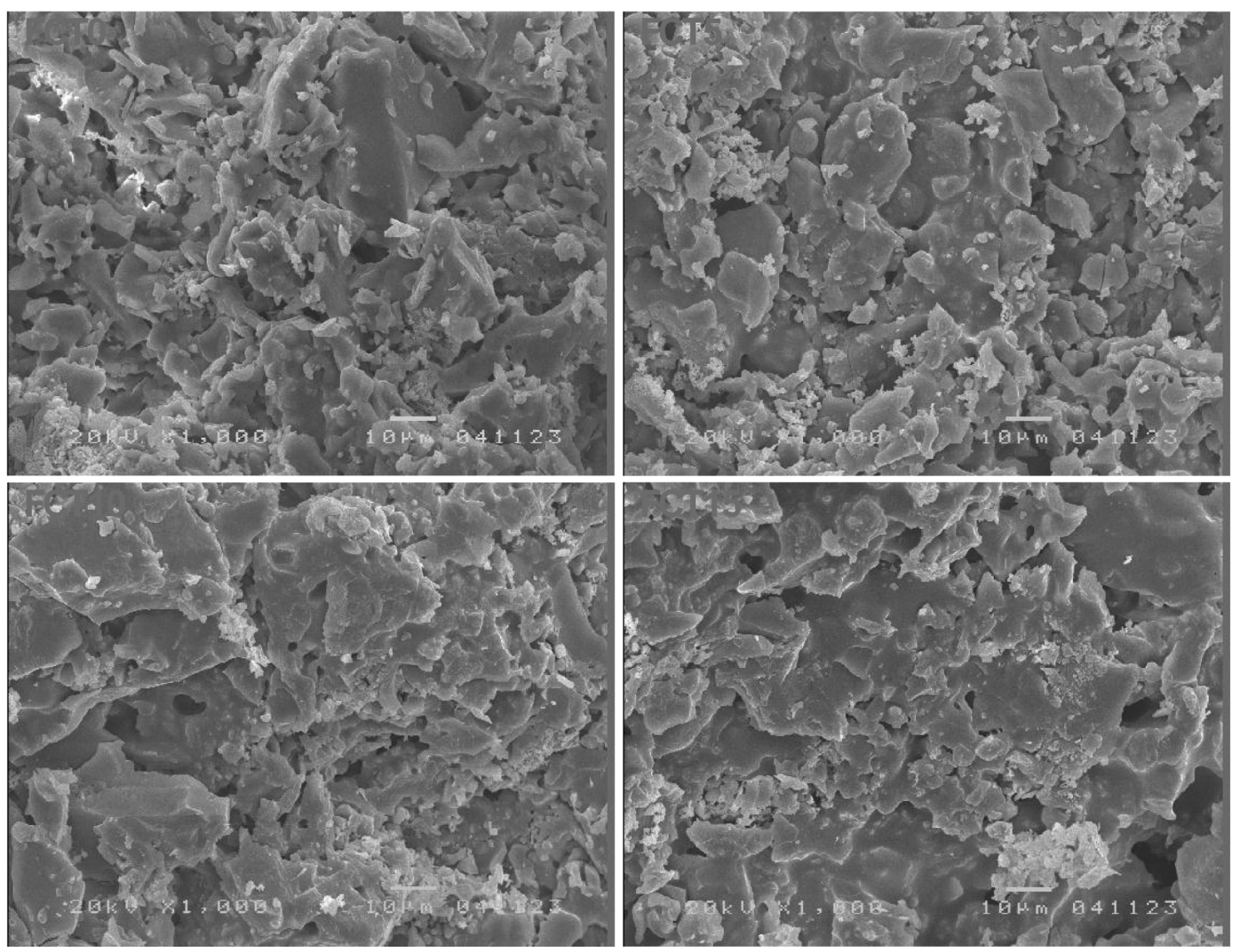

Fig. 6. SEM micrographs of the fly ash-clay-tailing systems sintered at $1100^{\circ} \mathrm{C}$.

미의 첨가량이 증가와 함께 치밀화가 진행되어 기공이 소멸되거나 크기가 감소함을 관찰할 수 있으며 이는 소 성시 광미의 $\mathrm{Fe}_{2} \mathrm{O}_{3}$ 가 점토의 알칼리 성분과 함께 소성 시 액상을 유도하여 치밀화에 기여한 것으로 생각된다.

\section{6. 시편의 물리적 특성}

광미의 첨가량과 열처리 온도에 따른 시편의 흡수율

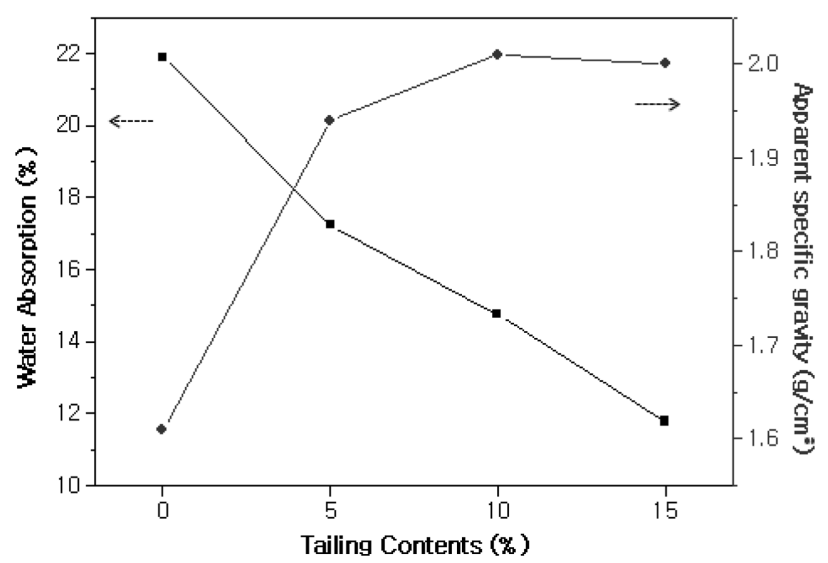

Fig. 7. Water absorption for the fly ash-clay-tailing systems sintered at various temperature with tailing contents.
(진밀도), 압축강도를 Fig. 7과 Fig. 8에 각각 나타내었다. 흡수률과 진밀도는 광미의 첨가량이 증가함에 따라 감소 하는 경향이 나타나는데 이는 광미의 성분 중 $\mathrm{Fe}_{2} \mathrm{O}_{3}$ 가 융제 역할을 하여 치밀화에 기여하는 것으로 생각된다. 압축강도는 광미의 첨가한 경우 광미를 첨가하지 않은 경우에 비하여 압축 강도가 약 $100 ~ 300 \mathrm{kgf} / \mathrm{cm}^{2}$ 정도

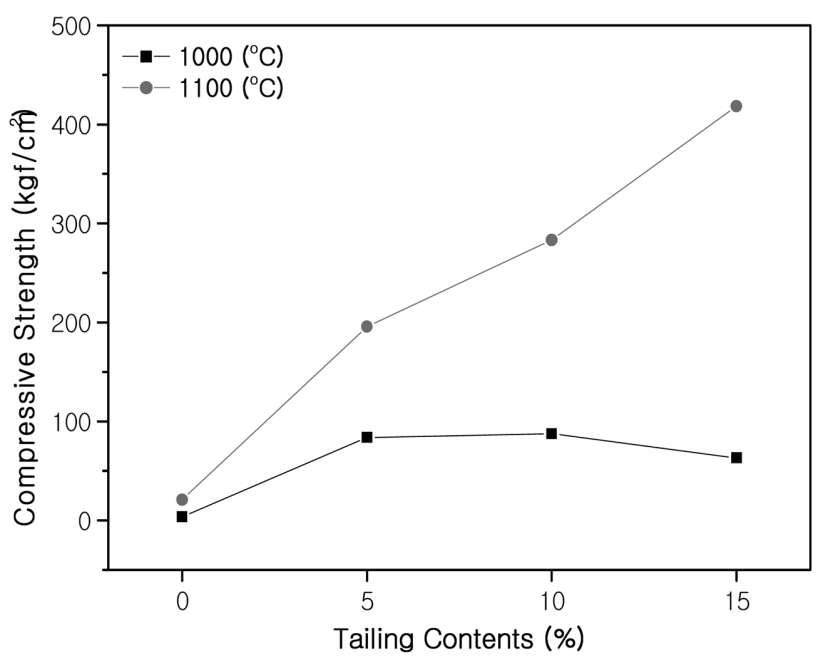

Fig. 8. Compressive strength for the fly ash-clay-tailing systems sintered at various temperature with tailing contents. 
Table 3

Heavy Metal leaching concentration of specimen by KSLT (unit: mg/l)

\begin{tabular}{|c|c|c|c|c|c|c|c|c|}
\hline Sintering temp. & $\mathrm{Cr}$ & $\mathrm{Zn}$ & $\mathrm{Pb}$ & As & $\mathrm{Cd}$ & $\mathrm{Cu}$ & $\mathrm{Hg}$ & $\mathrm{Ni}$ \\
\hline $1100\left({ }^{\circ} \mathrm{C}\right)$ & 0.006 & 0.013 & 0.001 & 0.140 & ND & 0.006 & ND & ND \\
\hline $1150\left({ }^{\circ} \mathrm{C}\right)$ & ND & 0.004 & ND & ND & ND & 0.002 & ND & ND \\
\hline Permission standard & $\begin{array}{l}\mathrm{Cr}^{6+} \\
1.5\end{array}$ & - & 3 & 1.5 & 0.3 & 1 & 0.005 & - \\
\hline
\end{tabular}

$\mathrm{ND}=$ Not detected

증가하는 경향이 나타났다. 소성온도가 $1,000^{\circ} \mathrm{C}$ 와 $1,100^{\circ} \mathrm{C}$ 에서의 시료는 흡수률이 높고 압축 강도가 낮은 것으로 소결이 계속 진행되는 것으로 생각된다. 시료 중 FCT15 가 흡수율 $11.78 \%$, 진밀도 $2.06 \mathrm{~g} / \mathrm{cm}^{3}$, 압축강도 418.4 $\mathrm{kgf} / \mathrm{cm}^{2}$ 로 가장 우수하며 이는 광미의 첨가량이 증가 할 수록 광미의 $\mathrm{Fe}_{2} \mathrm{O}_{3}$ 가 점토의 알카리성분과 함께 소성시 융제 역할을 한것으로 생각된다.

광미를 $5 \%$ 첨가한 $\mathrm{FCT} 5$ 시편에 대하여 $1000^{\circ} \mathrm{C}$ 와 $1150^{\circ} \mathrm{C}$ 에서 소성한 후 용출특성을 분석하여 Table 3에 나타내었다. $1150^{\circ} \mathrm{C}$ 로 소성한 경우 $\mathrm{Pb}$ 와 $\mathrm{Cd}$ 은 모두 불 검출되었으며, $\mathrm{As}$ 도 $1100^{\circ} \mathrm{C}$ 로 소성한 경우 $0.14 \mathrm{mg} / /$ 로 $1150^{\circ} \mathrm{C}$ 로 소성한 경우에도 검출되지 않았다. 그러나, 이 들 모두 지정폐기물 판정기준치를 만족시켰으며, 소성과 정에서 중금속들은 화합물과 액상으로 혼입되어 중금속 이 용출되지 않은 것으로 생각되고 이는 이전 연구의 바 닥재를 이용한 연구결과와도 일치한다[9].

\section{4. 결 론}

본 연구는 석탄회의 재활용과 광미내 중금속 고정화를 위해 석탄회-광미-점토계를 이용하여 물리화학적 특성과 중금속의 용출특성을 조사하였다.

석탄회의 화학조성은 $\mathrm{SiO}_{2} 33.01 \mathrm{wt} \%, \mathrm{Al}_{2} \mathrm{O}_{3} 28.54$ $\mathrm{wt} \%$ 이외에 $\mathrm{Fe}_{2} \mathrm{O}_{3}$ 와 알칼리성분 등이 함유되어 있다. 광미의 화학조성은 $\mathrm{SiO}_{2} 26.91 \mathrm{wt} \%, \mathrm{Fe}_{2} \mathrm{O}_{3} 22.97 \mathrm{wt} \%$, $\mathrm{Al}_{2} \mathrm{O}_{3} 3.42 \mathrm{wt} \% \mathrm{CaO} 24.25 \mathrm{wt} \%, \mathrm{SO}_{3} 14.39 \mathrm{wt} \%$ 그리 고 강열감량은 $6.55 \mathrm{wt} \%$ 로 나타났다.

석탄회-광미-점토계의 수축은 모든 시편이 $900^{\circ} \mathrm{C}$ 부근 에서 시작되고 있으며, $1000^{\circ} \mathrm{C}$ 부근에서 서서히 수축이 되어 $1100^{\circ} \mathrm{C}$ 부근에서는 급격히 수축하는 것을 볼 수 있으며 주결정상은 quartz, anorthite, albite, hematite, anhydrite, potassium상이 관찰되었다. Fly ash와 광미의 $\mathrm{CaO}$ 성분에 의해 소성온도가 증가함에 따라 quartz상의 피크 intensity가 감소하고 anorthite의 피크는 증가하는 것을 볼 수 있었다.

압축강도는 광미의 첨가한 경우 광미를 첨가하지 않은 경우에 비하여 압축 강도가 약 $100 ~ 300 \mathrm{kgf} / \mathrm{cm}^{2}$ 정도 증가하는 경향이 나타났다. 시료 중 $\mathrm{FCT} 15$ 가 흡수율
$11.78 \%$, 진밀도 $2.06 \mathrm{~g} / \mathrm{cm}^{3}$, 압축강도 $418.4 \mathrm{kgf} / \mathrm{cm}^{2}$ 로 가장 우수하며 이는 광미의 첨가량이 증가 할수록 광미 의 $\mathrm{Fe}_{2} \mathrm{O}_{3}$ 가 점토의 알카리 성분과 함께 소성시 융제 역 할을 한 것을 알수 있다. 소성과정에서 중금속들은 화합 물과 액상에 혼재되어 중금속이 용출되지 않은 것으로 생각된다.

\section{참 고 문 헌}

[1] N.J. Kim, H.Y. Cho, S.K. Kim, S.W. Kang, S.H. Min and T.Y. Lee, "Removal of hydrogen sulfide using porous artificial aggregates made by coal fly-ash", J. Kor. Soc. of Environ. Eng. 28(4) (2006) 407.

[2] K.N. Kim, J.H. Kwon and D.Y. Shin, "The manufacturing of fly ash-clay system ceramic bricks", J. Kor. Solid Wastes Eng. Soc. 18(5) (2001) 459.

[ 3 ] H.Y. Park, S.I. Seo, S.C. Kim and D. S. Kang, "Reburning of bottom ash in a coal-fired power plant and its effect on the plant management", J. Kor. Solid Wastes Eng. Soc. 24(5) (2007) 472.

[ 4 ] J.T. Song, S.D. Yun, D.W. Ryou and K. S. Han, "Manufacture and properties of coal fly ash-clay body", J. of the Korean Ceramic Society 33(7) (1996) 771.

[5] Y.S. Chu, J.K. Lee and K. B. Shim, "Preparation of lightweight aggregate using glass abrasive sludge and effects of pores on the aggregate properties", J. Kor. Cera. Soc. 42(1) (2005) 37.

[6] KS F 2503, "Testing method for density and absorption of coarse aggregate", Korean Standards Association, Korea (2007).

[ 7 ] KS L 3305, "Testing method for compressive strength of insulating fire bricks", Korean Standards Association, Korea (2007).

[ 8 ] J.S. Shin, "Characterization and agricultural utilization of fly ash", Mineral and Industrial. 8(1) (1995) 10.

[9] K.N. Kim and J.S Park, "Stabilization of heavy metals in mine tailing using coal bottom ash and clay and its recycling", J. Korean Solid Wastes Engineering Society 27(5) (2010) 398.

[10] ASTM C618-92a, "Standard Specification for Fly Ash and Raw or Calcined Natural Pozzolan for Use as Mineral Admixture in Portland Cement".

[11] K.N. Kim, J.H. Kwon and D.Y. Shin, "The manufacturing of fly ash-clay system ceramic bricks", J. Korean Solid Wastes Engineering Society 18(5) (2001) 459.

[12] J. Leja, "Surface chemistry of froth flotation", Plenum Press, New York (1982) 228. 
[13] R.M. Garrels and C.L. Christ, "Solutions, minerals and equilibria", Harper \& Row (1965) 450.

[14] K.N. Kim, H.S. Jung and H. Park, "Preparation of Shocrete coarse aggregate with low grade clay and coal ash", Journal of Korean Association of Crystal Growth
20(3) (2010) 147.

[15] J.T. Song, S.D. Yoon, M.S. Ahn and K.S. Han, "Mineral Compositions of the heated coal fly ash", Journal of Korean Association of Crystal Growth 5(2) (1995) 178. 